\title{
Influence of Logistic Performance on Global Competitiveness
}

\author{
Wahyu Widayat ${ }^{1}$, Heru Subiyantoro ${ }^{2}$, Machfud Sidik $^{3}$ \\ \{wahyu_murti@borobudur.ac.id ${ }^{1}$,heru_subiyantoro@borobodur.ac.id², machfud_sidik@gmail.com ${ }^{3}$ \} \\ Universitas Borobudur, Jakarta, Indonesia ${ }^{1,2,3}$
}

\begin{abstract}
The impact of logistics performance on global competitiveness and its consequences for economic growth are investigated in this study. Customs, infrastructure, international shipping, logistics service quality, monitoring and tracing, and timeliness are among the six criteria of the World Bank's Logistics Performance Index. The purpose of this study is to describe the causal relationship and test the hypothesis using an explanatory method (hypothesis testing study). The secondary data studied is panel data between 17 countries, namely ASEAN countries, several South Asian countries and several East Asian countries in the period 2007, 2010, 2012, 2014, 2016, 2018 according to the year of publication of the Logistics Performance Report The study model was built as a recursive linear model and analyzed with panel data using multiple linear regression analysis. According to the findings, exchange rates, interest rates and Net Export that simultaneously affect global competitiveness.
\end{abstract}

Keywords: Logistics Performance; Global Competitiveness; Influence

\section{Introduction}

In the era of globalization, especially during the implementation of the ASEAN Economic Community (AEC) nowadays, Indonesia and other countries in the region are required to further improve their economic competitiveness against global competition. Indonesia, which is located between the continents of Asia and the continent of Australia and between the Atlantic Ocean and the Indian Ocean, requires adequate logistics infrastructure, a reliable logistics system, and human resources professional logistics sector to support its competitiveness in the global market in order to realize the expected economic progress. as well as other ASEAN countries, South and East Asian countries.

In the perspective of trade competitiveness diagnostics, one way to determine international trade activities is economic competitiveness in the global market. Countries that have high competitiveness in the export market generally have a superior domestic market because the export market has high competition. Trade and productivity have a reciprocal relationship. Productive companies will transform into exporters and with the increase in the export market, these companies will become more productive. Reis and Farole (2012) mention that internal factors are the main obstacles such as financing, customs, logistics and lack of competition. In the low industrial connectivity to international markets, improving national logistics performance can be seen as a key strategy to increase global competitiveness and sustainable 
economic growth. Based on a report by the World Bank on the Logistics Performance Index (LPI) of July 26 2018, Indonesia's logistics performance is still lagging behind at the ASEAN level. Based on an index score scale of 1 to 5 , where a higher score represents higher logistics performance, Indonesia's LPI score in 2018 is still at 3.15 (ranked 46th in the world). Indonesia's logistics performance is below Singapore (4.0 - rank 7), Thailand (3.41 - rank 32), Vietnam (3.27 - rank 39), and Malaysia (3.22 - rank 41). Germany is ranked 1st in the world in logistics performance with an LPI score of 4.20. Nevertheless, Indonesia's logistics performance has tended to improve since it declined in 2010. Indonesia's geography, which is an archipelago, is still one of the biggest challenges for the government to improve national logistics performance. The development of logistics infrastructure by the government and inter-regional connectivity is expected to be the driving force behind Indonesia's improved logistics performance.

Logistics is the integration of various interests such as the movement of goods (movement) and storage of goods (storage) [1]. Logistics also aims to deliver various goods and materials with the right amount and place with the lowest total cost [2]. As a measure of international logistics performance from the World Bank, LPI measures and ranks the performance of a country's logistics sector based on six (6) trade dimensions from the results of a survey of international logistics professionals about that country. The dimensions analyzed are based on the latest research, both Logistics experts participating in international freight transport/expedition have both theoretical and empirical knowledge, as well as actual experience. The six dimensions are as follows: 1) Customs (customs efficiency and border clearance); 2) Infrastructure (quality of trade and transportation infrastructure - ports, airports, rail networks, road networks, information technology); 3) International shipments (easy transportation arrangements at competitive prices); 4) Logistics services quality (quality and competence of logistics services - trucking, expedition/forwarding, and customs brokerage); 5) Tracking and tracing (ability to track and trace catered goods); 6) Tracking and tracing (ability to track and trace catered (the frequency with which shipments arrive at their destination on time or ahead of schedule).

In relation to efforts to improve Indonesia's logistics performance, Law No. 17 of 2008 concerning Shipping is the starting point for improving the national logistics system. The regulation requires domestic shipping to be carried out by Indonesian-flagged ships and the implementation of the cabotage principle at Indonesian ports. In the last ten (10) years, the application of the cabotager principle can drive national economic growth and is quite effective in absorbing labor and investment. Regulation of the Minister of Transportation No. 8 of 2011 concerning Multimodal Transportation, which is a derivative of Law No. 17 of 2008, regulates the transportation of goods and has provided certainty for the multimodal transport business in logistics activities. The improvement of the logistics system that is of concern to the government is the existence of business certainty, reduced logistics costs and increased resource competence, which becomes a reference in the assessment of the ASEAN region's logistics system with 10 (ten) concentrations, namely: 1) 2) storage and warehousing services, 3) freight transport agency services, 4) other auxiliary services, 5) courier services, 6) packaging services, 7) customs clearance services, 8) international maritime freight transportation excluding cabotager, 9) international rail freight transport services, and 10) international road freight transport services.

In its relevance to national Based on the 2018 World Economic Forum report on Global Competitiveness, logistics performance Index (GCI), Indonesia's global competitiveness is also still lagging behind the ASEAN countries, several South Asian countries and several East Asian countries. Based on an index score scale of 1 to 7 , where a higher score represents 
higher global competitiveness, Indonesia's GCI score in 2018 is still at 4.89 (ranked 45 th in the world). Indonesia's global competitiveness is below Singapore (6.01 - ranked 2), Malaysia (5.46 - ranked 25th), and Thailand (5.05 - ranked 38th), but is still superior to Vietnam (4.49 - ranked 77th). ). Meanwhile, Hong Kong (5.53 - ranked 6), Japan (5.49 - ranked 9) and South Korea (5.07 - ranked 26). The United States is ranked 1st in the world in global competitiveness with a GCI score of 6.14. However, in the period 2007-2018, Indonesia's global competitiveness tends to increase. Based on this, the goal of this research is to determine the impact of logistics performance on global competitiveness.

\section{Literature Review}

\subsection{Logistics Performance}

The main activities on the historical performance of logistics and physical distribution consist of Transportation and storage are two different things. Transportation and storage are two distinct operations. Transportation, according to Swastha, is the process of transporting things from one place to another by using roads that use channels between institutions and consumers [1]. Meanwhile, storage is the process of maintaining as long as the goods are still needed. The management of the flow of goods can be carried out by logistics management starting from taking goods from suppliers and sending them to their storage and distribution areas. Services and information about products are provided in logistics management.

Strategically that logistics is a process of managing the flow from the place of origin to the point of consumption of a number of raw materials, inventories in process, and inventories of finished commodities (Daniel, 2001:31). Distribution channels to consumers are carried out through a logistics process. The economic sector is influenced by the logistics system, especially cargo transportation, which generally has a very long distance from one place to another. Usability, time and place constitute logistics operations and are important aspects of corporate and government operations. The emphasis on logistics management is how to manage goods starting from planning, determining needs, procurement, storage, distribution, maintenance, and elimination of goods to achieve the goals that have been set. Chopra (2007) In terms of demand, operations, purchasing, and logistics process management, supply chain management is defined as a holistic and strategic approach.

The job of logistics management is to design and manage systems to handle the flow of raw materials and finished commodities [1]. Logistics management, according to Bowesox (2002:13), is unique in that it is both one of the oldest and one of the newest corporate operations. People have been performing logistics operations (location, facilities, transportation, inventory, communication, and administration \& storage) since the dawn of commercial specialization. Logistics is an important aspect of channel operations. The overall goal of logistics management is to create a profit by striking a balance between expenses and revenues [1]. In the logistics process, functions are implemented or performed simultaneously by channel members. The movement of goods in one direction to the customer's final location is the most economical physical movement. According to Simamora (2000:731), customer service is a channel system that has the ability to provide satisfaction for the needs of customers, industrial users, or channel intermediaries.

Time of order cycle is the time required by the company to receive, process, and deliver an order. Reliability is related to the reliability of delivery which is an element of service for companies in distributing goods on time. Communication between buyers and sellers early on 
both parties can find solutions to problems faced as soon as possible. Ease of a flexible system so that it can accommodate needs for various customers. According to Irawan, the choice of logistics managers to carry out a combination of transportation and storage in the marketing channel [3]. Logistics channel is a combination of own logistics and general logistics which can be categorized as moving goods in 3 kinds of options, namely: fully using own tools; using agents; using a combination of general logistics and own logistics.

\subsection{Global Competitiveness}

According to Porter (1990) in the PPSK-BI book (2008) states that "productivity" at the national level is a Competitiveness as a term that can be used at the national level. The output value of a set of operations with a number of inputs is called productivity. "The amount and rate of change in value added per unit of input is a measure of competitiveness," according to the World Bank. National competitiveness is a wide notion that considers competitiveness not only at the micro level of the organization, but also at the macro level. These characteristics can be firm-, region-, or country-specific.

Global competitiveness is defined by the World Economic Forum (WEF), which publishes the Global Competitiveness Report, as "the ability of a national economy to generate high and sustained economic growth." The focus of economic growth is on proper policies and institutions, as well as other economic qualities that promote the realization of high and sustained economic growth. The World Competitiveness Yearbook is published by the Institute of Management Development (IMD), which defines global competitiveness as "a country's ability to develop added value in order to improve national income by managing and processing, attractiveness and aggressiveness, Globality and closeness, as well as integrating linkages, are all factors to consider. these economic and social linkages models". Global competitiveness has a non-uniform definition, although there is a common opinion about what should be done to increase global competitiveness [4].

In the Global The World Economic Forum's Competitiveness Report uses the Global Competitiveness Index (GCI) to measure and rank a country's global competitiveness based on twelve (12) pillars that determine economic competitiveness that enable the national economy to achieve sustainable economic growth and long-term prosperity. These twelve pillars measure the national economic and business environment of a country, both quantitatively from various national and international organizations and qualitatively based on a survey of executive opinion of companies that do business in the country (forum's executive opinion survey). The determinants of competitiveness can be grouped into the first group of basic requirements pillars, namely the key to a factor-driven economy (an economy driven by basic factors) as the first stage of development and country competitiveness, the second group of efficiency enhancing pillars. (efficiency enhancers), which are the third group of pillars of innovation and sophistication elements, which is the key to an innovation-driven economy, is the key to an efficiency-driven economy as the second stage of development and country competitiveness economy (innovation-driven economy) as the third stage of development and country competitiveness.

Starting in 2018, the World Economic Forum has adjusted its GCI measurement methodology to the concept of the Industrial Revolution 4.0 which emphasizes the importance of human capital, agility (the ability to operate quickly and easily), resilience (the ability to recover quickly from various difficulties), and innovation to achieve economic success. Within the framework of GCI 4.0, a country's global competitiveness is organized into 12 pillars of productivity main drivers in four (4) categories, namely: Human capital, markets, 
and the innovation ecosystem all play a role in creating an enabling environment. ecosystem of innovation The following pillars make up the Enabling Environment category: Institutions; Infrastructure; ICT adoption; Macroeconomic stability There are two pillars in the Human Capital category: 5) Health and 6) Skills. The following pillars make up the Markets category: 7) The product market; 8) The labor market; 9) The financial system; and 10) The market size The following pillars make up the Innovation Ecosystem category: 11) Business dynamism and innovation 12) Innovation capability. Although in a different category, where the indicators have also been modified - some are maintained and some are updated, broadly speaking, the pillars in GCI 4.0 are relatively the same as the previous ones. GCI 4.0 is no longer aggregated based on the weighting of pillar groups/categories according to the stages of development (economics based on factors, economics based on efficiency, and economics based on innovation) of each country. In GCI 4.0, each productivity pillar is given equal weight.

\section{Methodology}

The population in this study are ASEAN countries, several South Asia countries and several East Asian countries, namely ASEAN countries: Cambodia, Laos, Brunei Darussalam, Philippines, Indonesia, Malaysia, Vietnam, Thailand, and Singapore. Furthermore, several India, Pakistan, Bangladesh, and Sri Lanka are South Asian countries, while China, Hong Kong, South Korea, and Japan are East Asian countries during the entire development period. Meanwhile, the sample studied was the development period in 2007 - 2018, namely 2007 , 2010, 2012, 2014, 2016, and 2018 (6 years). The year under study is based on its conformity with the year of publication of inter-country logistics performance by the World Bank.

Research variables consist of independent variables, intermediate variables, and dependent variables. The independent variable is Logistics Performance which consists of: Customs, International Shipments, Quality of Logistics Services, Tracking and Tracing, Timeliness (X1), and Infrastructure (X2), Exchange Rate (X3), Interest Rate (X4) and Net Export (X5 ) and the intermediate variable is Global Competitiveness (Y) and the dependent variable is Economic Growth $(Z)$.

The A documentation study was used as a data collection approach in this investigation. The World Bank's Logistics Performance Report and Economic Growth Report, as well as the World Economic Forum's (WEF) Global Competitiveness Report, both included documentation studies as well as the Central Statistics Agency (BPS) and Bank Indonesia (BI) directly or through the websites of each institution. The data collected are logistics performance index data, exchange rate data, interest rate data, net export value, global competitiveness index, and Gross Domestic Product (GDP) between ASEAN countries, several South Asian countries and several East Asian countries for 6 years, namely 2007, 2010, 2012, 2014, 2016, and 2018. The number of observations collected is 17 countries x 6 years $=102$ observations. While the execution uses the EVIEWS econometric program.

The research design uses an explanatory study or hypothesis testing study with a quantitative approach with the aim of explaining the results of hypothesis testing about the relationship between variables, which explains the causal relationship (cause and effect) or the influence between variables as has been modeled in the research paradigm, namely the influence between performance dimensions. logistics, exchange rates, interest rates and the value of net exports on global competitiveness and their impact on economic growth. The quantitative approach is in line with the use of quantitative data in the measurement of 
variables and quantitative/statistical methods in the analysis of the influence between variables (Cresweel, 2010: 24).

The statistical method used in the study or The Ordinary Least Square (OLS) approach was used for linear regression analysis to determine the effect between variables with the recursive model. Regression analysis is used to examine the pattern of the relationship between one or more causal variables (exogenous) to one effect variable (endogenous). The entire data processing and analysis process in this study was carried out with the help of the EViews 10 for Windows computer program.

The simultaneous influence of logistics performance on global competitiveness shows that the integration of logistics performance improvement in all aspects; both quality, tracking, tracing, and timeliness of customs, infrastructure, international shipments, and logistical services as well as the performance of exchange rates, interest rates and net export, synergistically have the ability to increase global competitiveness. Similarly, the research findings on the positive effects partially or simultaneously from quality, tracking, tracing, and timeliness of customs, infrastructure, international shipments, and logistical services and exchange rates, interest rates and net export show that the aspects of logistics performance, exchange rates and interest rates increase. and this net export is effectively able to encourage higher global competitiveness. The logistics performance is a key strategy for achieving global competitive advantage and has a more dominant influence. Logistics performance serves as a primary factor. Meanwhile, the exchange rate, interest rate and net export are secondary factors. In improving economic connectivity, both are also the base factors that determine the overall supply-chain performance. Increasing the performance of logistics infrastructure and the quality of logistics services will increase global competitiveness and at the same time encourage the effectiveness of overall logistics performance, including aspects of Customs, logistics service quality, foreign shipments, tracking and tracing, and punctuality are all issues that need to be addressed. and exchange rates, interest rates, net export in achieving global competitive advantage. Improved infrastructure performance is indicated by the increasing quality of trade and transportation infrastructure, both ports, airports, rail networks, road networks, and information technology.

The results of the study which show that there is a positive influence of global competitiveness on economic growth are in accordance with the diagnostic theory of trade competitiveness and the theory of economic growth. As Kuznets refers to (in Jhingan, 2004), increasing a country's global competitiveness will increase economic growth or the expansion of a country's ability to give various forms of economic products to its people This skill develops in tandem with technology advancements and the necessary institutional and ideological changes. as a reflection of increasing global competitiveness. High global competitiveness, namely high productivity, will enable the national economy to achieve sustainable economic growth and long-term prosperity (Porter, 1990; World Bank).

Increased competitiveness is marked by increased productivity of As a factor-driven economic driver, basic requirements (institutions, entire infrastructure, macroeconomic stability, health and primary education); efficiency enhancers (higher education and training, goods market efficiency, labor market efficiency, financial market sophistication, technological readiness, market size) as drivers of an efficiency-driven economy; and innovation and sophistication factors as drivers of an efficiency-driven economy (business sophistication, innovation) as drivers of the innovation-driven economy (World Economic Forum, 2018). All the results of this study develop the results of research by Bizoi and Sipos (2014) and show that global competitiveness is an intervening variable that mediates the Economic growth and the impact of logistics performance Bizoi and Sipos (2014) reveal in 
their comparative analysis that European Union nations with better logistics performance include able to produce higher Gross Domestic Product.

\section{Results and Discussion}

The results of the analysis of the model of the influence of logistics performance on global competitiveness and its implications for economic growth show the same results. Logistics performance Infrastructure (customs, foreign shipping, logistics service quality, tracking and tracing, timeliness), exchange rates, interest rates and net export together or simultaneously affect global competitiveness and have implications for economic growth. If compared, the influence model with the highest level of conformity is the model of the effect of logistics performance, exchange rate, interest rate and net export on global competitiveness with an adjusted coefficient of determination (Adjusted $\mathrm{R}^{2}$ ) of $95.60 \%$. Furthermore, the model of the influence of global competitiveness on economic growth with Adjusted $\mathrm{R}^{2}$ of $67.020 \%$. It appears that the model of the effect of logistics performance, exchange rate, interest rate and net export on global competitiveness and its implications for economic growth has met the level of model suitability or adequate predictive ability, which is above $50 \%$ (Baye's measure).

The results of the study which show that there is a partially significant effect of logistics performance, exchange rate and net export on global competitiveness are in accordance with trade competitiveness diagnostics theory. Increasing international trade activities along with improved logistics performance, exchange rates, interest rates and net export is a key strategy to develop economic competitiveness in the global market. As referred to by Reis and Farole (2012), the low performance of logistics, the exchange rate and the value of net exports is one of the main obstacles for developing countries, which are behind the border, to compete in international trade. Through logistics performance, high exchange rates and net export value, the process of delivering the right amount of finished goods/materials to the right place at the right time and with the lowest total cost can be carried out effectively [2]. Increased connectivity of production sectors on international markets due to improved logistics performance, exchange rates, interest rates and the value of national net exports will boost global competitiveness. The results of this study support the results of Anatan's research (2010) which shows that logistics performance, exchange rate and net export value are determinants in achieving competitive advantage of an entity. Meanwhile, the partial insignificant effect of interest rates indicates the ineffective role of the interest rate performance aspect in achieving global competitiveness.

\section{Conclusions and Suggestions}

\subsection{Conclusion}

Based on the best and most appropriate model for estimating panel data, the Fixed Effect Model (FEM) has been selected. It can be concluded that the Customs, foreign shipments, logistics service quality, tracking and tracing, and punctuality are all aspects of logistics performance (X1), partially has a positive and. significant to competitiveness. From the results of this modeling, it shows that the better the quality of Logistics Performance, the better the Global Competitiveness of a country. 
Global competitiveness has a positive effect on economic growth. This finding shows that increasing global competitiveness has the ability to increase economic growth. Increasing global competitiveness is indicated by increasing productivity of a factor-driven economy's essential necessities (institutions, full infrastructure, macroeconomic stability, health, and primary education); efficiency enhancers (higher education and training, goods market efficiency, labor market efficiency, financial market sophistication, technological readiness, market size) as driver of an efficiency-driven economy; and variables such as innovation and sophistication (business sophistication, innovation) as the driving force of the innovationdriven economy. The forecasting ability of the economic growth model, which is relatively lower than the global competitiveness model, has theoretical implications that there are other factors outside of global competitiveness that also affect economic growth.

Indonesia's position in global competition in 2018 as shown in this model is still ranked 45 th in the world. Indonesia's global competitiveness among ASEAN countries is below Singapore (6.01 - ranked 2), Malaysia (5.46 - ranked 25th), and Thailand (5.05 - ranked 38 th), but is still superior to Vietnam (4.49 - rank 77). Meanwhile, Hong Kong (5.53 - ranked 6), Japan (5.49 - ranked 9) and South Korea (5.07 - ranked 26). The highest ranking was achieved by the United States, which was ranked 1st in the world.

\subsection{Suggestion}

As a practical suggestion, to increase global competitiveness which can have implications for economic growth; it is suggested to the government to evaluate the national logistics performance development policy; especially the carrying capacity of Customs, logistics service quality, foreign shipments, tracking and tracing, and timeliness are all issues which need to be handled and its integration with other aspects of logistics performance. Infrastructure is the basic determinant of supply chain performance as a whole in increasing national (intra-regional and inter-regional) and international economic connectivity. The government is also advised to encourage sustainable global competitiveness based on policies to improve logistics performance in a sustainable manner, namely by increasing logistics operational performance in a synergistic manner through increasing the carrying capacity of logistics services quality, tracking and tracing, timeliness, as well as increasing the effectiveness of customs, infrastructure, international shipments, value for money. net exports as well as exchange rates, competitive interest rates. Infrastructure carrying capacity is not only related to the availability, capacity, and capability of each logistics infrastructure, but also to its integration and connection in the network. The increasing performance of customs, infrastructure, international shipments, and net export value must also be balanced by increasing performance in customs, infrastructure, international shipments, and net export synergistically. In achieving competitive dwelling time performance, infrastructure and logistics services quality performance in shortening the time for customs clearance, customs brokerage services, and post-customs clearance, it needs to be balanced with customs performance in shortening customs clearance times.

\section{References}

[1] Swastha, B. Manajemen Pemasaran Modern. Yogyakarta: Liberty. (1990).

[2] Bowersox, D.J. Supply Chain Logistics Management. New York. The. McGraw-Hill Companies, Inc. (2002). 
[3] Basu Swastha, DH dan Irawan. Modern Marketing Management., Yogyakarta:Liberty. (1990).

[4] Sachs, Torsten; Wille, Christian; Boike, Julia; Kutzbach, Lars: Eddy Covariance raw data from Samoylov station, Lena River Delta, Siberia in 2006. GeoForschungsZentrum Potsdam,

PANGAEA, https://doi.org/10.1594/PANGAEA.745602 (2008). 